\title{
CONCEPT OF SETTLEMENT IN JULAH CULTURAL VILLAGE AS A PART OF BALI AGA VILLAGE REVIEWED ON RITUAL, BELIEF, AND DOMESTIC ROUTINE ASPECTS
}

\author{
${ }^{1}$ Dewa Nyoman Angga A.B.. ${ }^{2}$ Dr. Ir. Y. Basuki Dwisusanto, M.Sc. ${ }^{3}$ Franseno Pujianto, \\ S.T., M.T. \\ ${ }^{1}$ Student in the Bachelor's (S-1) Study Program in Architecture \\ at Parahyangan Catholic University \\ ${ }^{2}$ Senior lecturer in the Bachelor's (S-1) Study Program in Architecture \\ at Parahyangan Catholic University \\ ${ }^{3}$ Senior lecturer in the Bachelor's (S-1) Study Program in Architecture \\ at Parahyangan Catholic University
}

\begin{abstract}
Reidfiled (1953) states that new buildings built within the vernacular architecture physically manifest and perpetuate the cultural norms and building that accumulate in them. In essence, Balinese culture is classified as an expressive type that emphasizes the religious and aesthetic values (art) as the dominant value, so the value is always prominent and present along with other elements in everyday life (Pujaastawa, 2014). This research describes Desa Adat Julah sattlement's concept as Bali Aga Village which still survive, viewed from cultural aspect, ceremony and daily routine as dominant element and the relation of architectural form to the activity in it. This study applies the theory of Vernacular Architecture Paul Oliver: (1) Religion and Belief, (2) Ceremony and Ritual, and (3) Domestic Routine.The architectural elements of Desa Adat Julah classified into order, space and form based on D. K. Ching theory.

The research shown, beliefs factors led the village zonation based on natural factors such as mountains (ulun) and sea (teben). In ceremonial activity, the main circulation path can be called the "center" of village orientation. The concept of dwelling yard is associated with the catuspatha. The catuspatha generates a "natah" space. The canges of domestic routine also changed its form.
\end{abstract}

Key Words: Desa Adat Julah, belief, ritual and domestic routine, form, space and order, concept of settlement.

\section{KONSEP PERMUKIMAN DESA ADAT JULAH SEBAGAI DESA BALI AGA DITINJAU PADA ASPEK UPACARA, KEPERCAYAAN, DAN RUTINITAS SEHARI-HARI}

\author{
${ }^{1}$ Dewa Nyoman Angga A.B.. ${ }^{2}$ Dr. Ir. Y. Basuki Dwisusanto, M.Sc. ${ }^{3}$ Franseno Pujianto, \\ S.T., M.T. \\ ${ }^{1}$ Mahasiswa S1 Program Studi Arsitektur Universitas Katolik Parahyangan \\ ${ }^{2}$ Dosen Pembimbing S1 Program Studi Arsitektur Universitas Katolik Parahyangan \\ ${ }^{3}$ Dosen Pembimbing S1 Program Studi Arsitektur Universitas Katolik Parahyangan
}

\begin{abstract}
Abstrak- Reidfiled (1953) menyatakan bahwa bangunan baru yang dibangun dalam lingkup arsitektur vernakular secara fisik memanifestasikan dan mengekalkan norma kebudayaan dan seni bangunan yang terakumulasi di dalamnya. Pada hakikatnya kebudayaan Bali tergolong tipe ekspresif yang mengedepankan nilai religius dan estetika (seni) sebagai nilai dominan, sehingga nilai tersebut selalu menonjol dan hadir menyertai unsur-unsur lainnya dalam kehidupan sehari-hari (Pujaastawa, 2014). Tujuan dari penelitian ini adalah mendeskripsikan konsep permukiman Desa Adat Julah sebagai Desa Bali Aga yang masih bertahan, dilihat dari aspek budaya,
\end{abstract}

${ }^{1}$ Corresponding Author: angga.arsika@gmail.com 
upacara, dan rutinitas sehari-hari sebagai unsur dominan dan bagaimana keterkaitan wujud arsitektur terhadap aktivitas di dalamnya. Penelitian ini menerapkan teori Arsitektur Vernakular Paul Oliver yaitu (1) Agama dan Kepercayaan, (2) Upacara dan Ritual, serta (3) Rutinitas sehari-hari. Untuk memudahkan analisis maka elemen arsitektur Desa Adat Julah diklasifikasikan dalam wujud tatanan, ruang, dan bentuk berdasarkan teori D.K.Ching.

Berdasarkan hasil penelitian, faktor kepercayaan menyebabkan adanya pembagian zonasi desa berdasarkan faktor alam seperti gunung (ulun) dan laut (teben). Secara ritual, jalur sirkulasi utama dapat disebut sebagai "pusat" orientasi desa. Konsep penataan pekarangan huniannya terkait dengan konsep catuspatha. Konsep catuspatha ini juga menghasilkan ruang natah yang terkait dengan proses ritual yang ada. Faktor rutinitas juga telah menyebakab adanya perubahan terhadap bentuk yang ada.

Kata Kunci: Desa Adat Julah, kepercayaan, ritual dan rutinitas sehari-hari, bentuk, ruang dan tatanan, konsep permukiman.

\section{PENDAHULUAN}

Terdapat berbagai ragam arsitektur yang ada di Bali. Gantini (2009) dalam tulisannya yang berjudul Warna-Warni Bali setidaknya menyebutkan terdapat sembilan ragam arsitektur Bali. Kesembilan ragam tersebut yaitu 1) Arsitektur Bali Majapahit, 2) Arsitektur Still Bali, 3) Arsitektur "Bali-Style"I, 4) Arsitektur Bali Modern, 5) Arsitektur Bali-Islam, 6) Arsitektur Bali-Kristen, 7) Arsitektur Bali-Kolonial, 8) Arsitektur Bali Aga, dan 9) Arsitektur Bali Kuna. Oleh karena itu, Bali sangat memiliki kekayaan ragam Arsitektur yang menarik untuk diteliti. Salah satu yang menarik untuk diteliti yaitu ragam arsitektur tradisional Desa Bali Aga.

Desa Adat Julah merupakan salah satu desa Bali Aga. Desa ini terletak di Bali Utara, tepatnya di Kabupaten Buleleng dan kurang lebih berjarak 35 kilometer dari pusat kota Singaraja. Desa ini mudah diakses melalui jalan raya antar kabupaten yang menghubungkan Kabupaten Buleleng dan Kabupaten Karangasem. Berdasarkan jenis jaringan jalannya, jalan raya ini dikategorikan sebagai jalan raya antar provinsi. Oleh karena itu desa ini dapat dikatakan lebih terbuka jika dibandingkan desa Bali Aga lainnya yang pada umumnya terletak di pegunungan dan beradarkan sulit pencapaiannya.

Desa Adat Julah dapat dikatakan desa tua di Bali. Hal ini dapat dilihat melalui situs peninggalan yang ditemukan di desa ini. Situs ini bernama situs Batu Upit. Situs Batu Upit terletak di selatan permukiman warga, tepatnya ke arah perbukitan. Di dalamnya terdapat peninggalan batu jaman megalitik yang diperkiran berusia 2000 tahun. Selain itu, bukti lebih jauh tentang keberadaan kehidupan peradaban pra-sejarah yaitu ditemukannya peninggalan tembaga, kapak jaman proto, palu, dan hand-adze-semacam cangkul (Soejono 1962). Penemuan lebih lanjut menemukan adanya peninggalan batu berstruktur seperti terasing (punden berundak) yang menyerupai peninggalan jaman megalitkum. Punden berundak ini dipercayai digunakan sebagai tempat penyembahan nenek moyang untuk meminta keselamatan dan meminta rejeki pada masyarakat. (Sutaba 1976;1980).

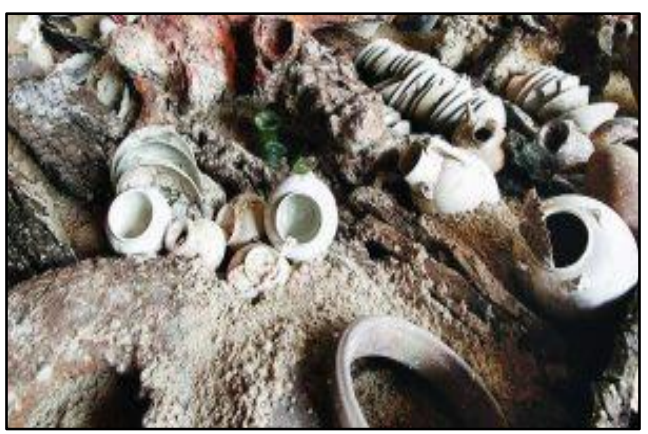

Figur 1. Peninggalan peradaban prasejarah di situs Batu Upit

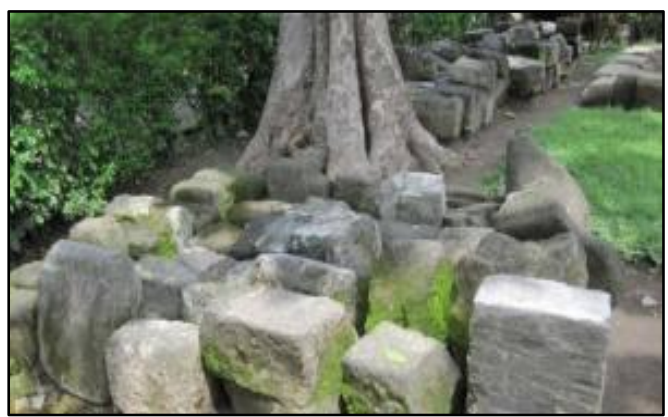

Figur 1. Peninggalan batu punden berundak jaman megalitik 
Secara konstrukusi dan material bangunan, desa ini terbuat dari material dan sistem yang sederhana, seperti misalnya material bata tanah liat dengan sistem tanah liat di-pol-pol. Struktur yang digunakan juga menggunakan kayu yang ada disekitar perkebunan warga seperti kayu jati dan juga kayu intaran. Namun saat ini, tidak banyak bangunan dengan sistem dan material tradisional seperti ini yang masih bertahan. Beberapa bangunan pun harus dihancurkan karena faktor usia bangunan serta menyesuaikan dengan kebutuhan saat ini. Material bangunan yang digunakan kini lebih modern. Banyak yang telah beralih menggunakan material keramik dan dinding dan struktur beton berulang.

Meskipun demikian, hasil pengamatan menunjukan bahwa perkembangan hunian terkini masih memiliki tatanan yang serupa. Hal ini juga senada dengan pernyataan Robert Reidfiled (1953) bahwa bangunan baru yang dibangun dalam lingkup arsitektur vernakular secara fisik memanifestasikan dan mengekalkan norma-norma kebudayaan dan seni bangunan yang terakumulasi di dalamnya.

Hal ini berarti terdapat kebudayaan yang tetap menjadi pedoman masyarakatnya dalam identitas mereka. Kebudayaan adalah sistem pengetahuan. Kebudayaan meliputi sistem ide gagasan yang terdapat di dalam pikiran manusia, sehingga dalam kehidupan sehari-hari kebudayaan itu bersifat abstrak. Sedangkan perwujudan kebudayaan adalah benda-benda yang diciptakan oleh manusia sebagai makhluk yang berbudaya, berupa perilaku dan benda-benda yang bersifat nyata, misalnya pola-pola perilaku, bahasa, peralatan hidup, organisasi sosial, religi seni dan lain-lain, yang kesemuanya ditujukan untuk membantu manusia dalam melangsungkan kehidupan bermasyarakat (Wikipedia, 2017).

Pada hakikatnya kebudayaan Bali tergolong tipe kebudayaan ekspresif yang mengedepankan nilai religius (agama Hindu) dan juga estetika (seni) sebagai nilai dominan, sehingga unsur-unsur religi dan seni menjadi begitu menonjol dan selalu hadir menyertai unsur-unsur lainnya (Pujaastawa, 2014). Ekspresi-ekspresi ini sangat terlihat dalam kehidupan sehari-hari masyarakatnya. Sehingga unsur-unsur inilah yang menjadi pedoman yang ideal berkehidupan bagi masyarakat Bali.

Arsitektur merupakan produk kebudayaan. Oleh karena itu permukiman juga salah satu produk kebudayaan. Kebudayaan merupakan ekspresi yang menonjol dalam masyarakat Bali. Melihat dari kuatnya kebudayaan pada masyrakat Bali, maka rumusan masalah penilitian ini yaitu mengukapkan konsep permukiman Desa Adat Julah sebagai Desa Bali Aga ditinjau berdasarkan aspek kebudayaannya, khususnya berdasarkan kepercayaan, upacara/ ritual, dan rutinitas sehari-harinya yang kemudian dikaitkan dengan wujud arsitekturnya dalam tatanan, ruang dan bentuk.

\section{KAJIAN TEORI}

Teori yang diterapkan dalam kajian ini mencakup teori yang berkaitan erat dengan konteks budaya, arsitektur, dan arsitektur vernakular, yang secara keseluruhan teori ini akan dianalisis berdasarkan substansinya, dan hasil dari kajian ini dapat ditelusuri substansi dan konsep. Teori yang digunakan dalam penelitian ini menggunakan teori Paul Oliver tentang arsitektur vernakular terkait dengan aspek dan ciri kebudayan. Adapun aspek ciri kebudayaan menurut Oliver yang digunakan pada penulisan ini yaitu (1) Agama dan kepercayaan (2) Ritual dan upacara, serta (3) Rutinitas sehari-hari. Elemen arsitektur Desa Adat Julah diklasifikasikan berdasarkan wujud arsitektur oleh D.K.Ching yaitu (1) tatanan, (2) ruang, dan (3) Bentuk. Arsitektur Bali Aga digunakan dalam tulisan ini untuk acuan Desa Adat Julah sebagai desa Bali Aga. Hal ini karena antara Arsitektur Desa Bali Aga dengan Arsitektur Bali pada umumnya tidak dapat disamakan karena memiliki sejarah dan kebudayaan yang berbeda. 


\subsection{KEBUDAYAN DAN ARSITEKTUR VERNAKULAR}

Agama dan Kepercayaan dalam Arsitektur Vernakular. Agama atau bentuk kepercayaan lainnya, baik itu takhayul, sihir ilmu gaib ataupun perdukunan, menciptakan kosmologinya sendiri untuk mengerti dan menjelaskan misteri kelahiran, kehidupan, kematian, kehidupan setelah kematian, penyakit, bencana alam, dan fenomena supranatural. Agama diseluruh dunia telah mengembangkan gagasan tentang jalan keselamatan, gaya hidup yang tepat dan tentang ide-ide bagaimana, di mana dan kegiatan seperti apa yang dapat menuntun kearah kebaikan hidup di dunia dan dunia akhirat. Beberapa komponen yang umumnya terdapat pada proses pencapaian ini misalnya, kebutuhan untuk kontempalasi akan peran manusia, binatang dan dunia. Kedua, yaitu kebutuhan untuk memuja dewa-dewi. Ketiga yaitu, menyucikan tempat para dewa, atau tempat untuk pemujaan. Keempat yaitu kebutuhan untuk merefleksikan diri. Hal ini telah menciptakan keragaman dan kekayaan tidak hanya dari segi ide atau gagasan yang ada di dalam agama tetapi juga terhadap arsitektur kepercayaan yang beragam. Gagasan yang bersifat kosmologi itu diwujudkan kedalam arsitektur vernakular (Lebeuf). Perwujudannya di dalam arsitektur dapat terlihat diberbagai macam hal seperti, perletakan lokasi, orientasi, penorganisasian ruang dalam, bentuk, dan artefak-artefak yang mengandung ekspresi simbol-simbol tertentu, maupun dekorasinya.

Upacara dan Ritual dalam Arsitektur Vernakluar. Sebagian besar ritual yang terkait dengan masyarakat vernakular melibatkan kontak dengan sesuatu yang bersifat sakral. Rangkaian ritual upacara seperti kelahiran, pembaptisan, inisiasi, pernikahan, dan kematian atau penguburan atau kremasi baru dapat dikatakan sah setelah melalui proses yang memiliki kekuatan spritual. Semakin besarnya ritual dan upacara di dalam masyarakat vernakular, hal ini akan melibatkan semacam akses yang sifatnya sakral. Makna simbolik arsitektur dan lanskap secara spasial menyediakan kerangka kerja dalam pelaksanaan ritual. Pengaturan ritual dapat didefinisikan sebagai hal yang menunjukkan hubungan antara area yang memiliki sifat simbolis dan dikaitkan dengan kelompok yang berbeda penggunaannya secara seremonial. Sehingga, antara pelaksanaan ritual akan mempengaruhi organisasi ruang, pelaksanaan serta kepercayaan sosial masyarakatnya. Struktur hubungan oposisi antara domain ini diciptakan oleh ambang batas, sumbu, orientasi, konsentrisitas, vertikalitas dan homologi umum.

Rutinitas Sehari-hari dalam Arsitektur Vernakular. Secara sehari-hari, perilaku yang menjadi rutinitas seorang individu adalah kunci dalam memahami struktur yang ada di dalam masyarakat. Meskipun terlihat duniawi dan terlihat sangat umum sehingga tampak tidak dapat 'terdiagnosa', namun kegiatan yang menjadi rutinitas sehari-hari masyarakat yang terjadi disekitar rumah merupakan komponen esensial dalam proses pembentukan budaya di mana masyarakat belajar kerangka konseptual yang spesifik. Hal ini memiliki arti bahwa orang belajar tentang apa yang perlu mereka ketahui untuk mengkategorikan ruang pribadi dan ruang orang lain dalam hirarki sosial, berdasarkan objek, ruang dan sikap yang membentuk dunia mereka (Pader).

\subsection{TATANAN, RUANG, DAN BENTUK SEBAGAI WUJUD ARSITEKTUR}

Menurut D. K. Ching (2008) kota, desa, kampung dan bangunan pada umumnya tersusun atas sejumlah ruang yang berkaitan satu sama lain menurut fungsi, jarak, atau alur gerak. Hubungan ruang-ruang suatu bangunan satu sama lain dan organisasi mereka menjadi pola-pola bentuk dan ruang yang saling terkait.Ruang dan bangunan-bangunan tersebut tersusun menjadi suatu tatanan yang memiliki kesatuan dan suatu organsasi ruang.

Ruang dapat terbentuk oleh kedua elemen pembentuknya yaitu, elemen vertikal dan juga horizontal. Ruang adalah suatu unsur hawa yang pada hakekatnya adalah tak berbentuk. Bentuk visual, dimensi dan skalanya, kualitas pencahayaannya, semua kualitas ini tergantung pada persepsi kita terhadap batas-batas spasial yang didefinisikan oleh elemen-elemen bentuk. 
Bentuk arsitektural adalah titik sentuh antara massa dan ruang. Bentuk-bentuk arsitektural, tekstur, material, modulasi cahaya dan bayangan, warna, semua berkombinasi untuk menghadirkan suatu kualitas ruang atau roh yang mengartikulasi ruang (Edmund N, 1974). Suatu perwujudan dari organisasi ruang yang merupakan hasil dari suatu proses pemikiran.Proses ini didasarkan atas pertimbangan fungsi dan usaha pernyataan diri/ekspresi (Hugo Haring). Hal ini menyebakan sebuah bentuk memiliki ekspresi yang menunjukan adanya pernyataan diri yang terkait dengan yang ingin ditampilkan sebagai identitasnya.

\subsection{KEBUDAYAN DAN ARSITEKTUR BALI AGA}

Menurut Acwin D (2009:2) Desa Bali Aga adalah desa tradisional tertua di Bali. Penduduk Bali Aga dulunya adalah penduduk yang menganut kepercayaan animisme dan dinamisme. Pada abad ke-14, Majapahit melalui Patih Gajah Mada, berhasil memasukkan pengaruh Hindu-Majapahit aliran Siwa-Budha pada masyarakat Bali dataran rendah. Penduduk Bali yang berbeda keyakinan kemudian melarikan diri ke daerah pegunungan kemudian mendirikan permukian yang tidak terpengaruh oleh keyakinan Bali dataran rendah. Pola kehidupan yang sangat nyata pada kehidupan masyarakat Bali Aga, menampakkan corak komunal yaitu suatu ciri yang menekankan bentuk kehidupan dalam situasi kebersamaan. "Corak kebersamaan nampak dalam mengerjakan suatu pekerjaan yang dilakukan secara gotong royong baik dalam situasi suka atau situasi duka" (N.D.Pandit Sastri, 1965, 94). Ciri kehidupan komunal. Salah satu bentuk kehidupan kebersamaan yang dapat terlihat sampai saat ini misalnya kegiatan kematian, upacara keagamaan, membuat rumah, ngeepin, dan sekaa.

Secara kepercayaan, masyarakat Desa Bali Aga dengan kekuatan gaib dan roh leluhur orang yang mempunyai posisi penting dalam keagamaan. Adanya konsep luan dan teben pada pola permukiman menunjukan konsep kepercayaan rwa Bhineda (dualisme).

Dalam buku PraSejarah dan Klasik di Bali yang dijelaskan oleh Made Geria, ciri khas permukiman Bali Aga adalah sebagai berikut :

1. Pola yang permukiman yang diterapkan adalah pola linear dengan struktur rumah berderet tanpa adanya tembok pembatas antara rumah yang satu dengan yang lainnya.

2. Halaman rumahnya tampak menyatu dengan rumah-rumah sekitarnya. Adanya kompleks yang menyebar membentuk sublingkungan yang berjauhan yang dihubungkan melalui jalan setapak ke desa induk.

3. Dalam penataan masing-masing wilayah mempunyai kekhasan sendiri seperti desa Tenganan dengan plaza berpola khusus.

4. Orientasi arah bangunan perumahan ke arah tempat yang lebih rendah, dengan tempat suci diletakkan pada tempat yang dianggap lebih tinggi.

5. Arah rumah tidak langsung mengarah pada jalan utama tetapi melalui jalan-jalan kecil yang ada didepan rumah (gang). Faktor yang menonjol adalah faktor kondisi alam, nilai utama pada arah gunung.

6. Pola lingkungan mendekati pola linear dengan lintasan jalan yang membentuk pola lingkungan yang sesuai dengan transisi lokasi kemiringan dan lereng-lereng alam

7. Konsepsi yang dikenal yaitu Tri Loka(3 dunia) yang dapat terlihat dalam pelaksanaan pengaturan struktur pekarangan yang terkait dengan kepercaaan adanya pandangan bahwa dunia atau alam semseta tersusun atas tiga bagian yaitu Bhur, Bhwah, dan Swah. Dalam diri manusia pandangan ini menjelma kedalam konsep Tri Angga (3 badan) yang secara horizontal dapat terlihat melalui pembagian area seperti bagian utama (hulu) tempat banunan suci, halaman tengah, dan halaman luar.

8. Penataan ruang tidak berlaku horizontal, namun vertikal dalam penentuan kesucian tempat diukur dari ketinggian yang diposisikan sebagai tempat yang disucikan. 
Konsep pengaturan secara vertikal ini berpola juga pada pembagian ruang di dalam rumah tampul roras, penempatan para-para yang strukturnya dibuatkan di atas paling atas sebagai tempat yang ditinggikan untuk tempat suci.

9. Rumah dibuat beratap rendah dan minim ventilasi.

Catuspatha.Catuspatha memiliki bentuk dasar palang (+) dalam istilah Bali disebut juga dengan tampak dara yang mitologinya terdapat dalam Lontar Catur Bumi. Tampak dara ini mengilhami koordinat Cartesius dalam matematika dan menjadi dasar swastika. Bila swastika merupakan simbol perputaran alam semesta, maka tampak dara (sumbu salib) merupakan simbul alam semesta. Tampak dara ini juga digunakan sebagai penangkal untuk menghindari malapetaka (Donder, 2001:15-16).

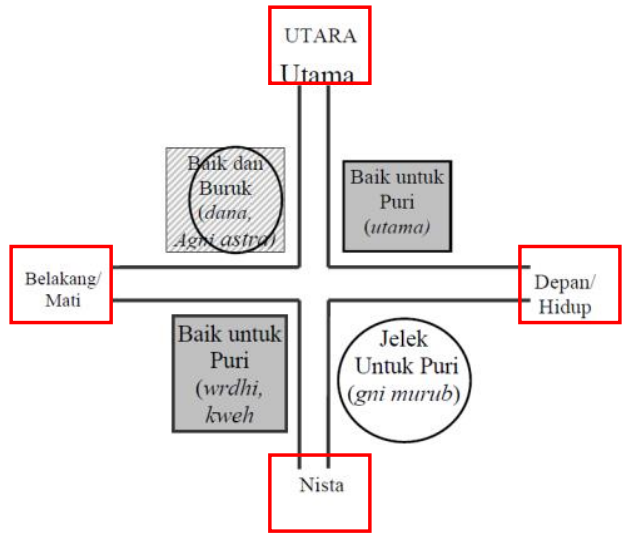

Figur 3. Konsep Catuspatha dalam Arsitektur Tradisional Bali (Sumber: Made Putra, 2005)

Dalam sistem pembagian tata ruang, Desa Adat Tenganan Pegringsingan mengikuti konsep "Tapak Dara", yaitu sebuah konsep pertemuan antara arah angin kaja-kelod (utaraselatan) yang merupakan simbol segara-gunung (laut-gunung) dan arah matahari kangin-kauh (timur-barat). Pertemuan kedua arah itu dipersepsikan sebagai perputaran nemu gelang (seperti lingkaran) dengan porosnya berada di tengah-tengah. Orang Tenganan menyebutnya 'maulu ke tengah' atau berorientasi ke tengah-tengah. Ini mengandung makna mencapai keseimbangan melalui penyatuan bhuwana alit (manusia dan karang paumahan atau pekarangan rumah) dengan bhuwana agung (pekarangan desa).

\section{METODA PENELITIAN}

Metode yang digunakan pada penelitian ini adalah metode deskriptif kualitatif. Datadata diperoleh dari: (1) Studi literatur dengan mempelajari mengenai kebudayaan Bali Aga dan Arsitektur Vernakular, (2) Pengamatan langsung ke Desa Adat Julah, dan (3) Melakukan wawancara kepada penduduk asli Desa Adat Julah.

\section{ANALISA}

\subsection{DESA ADAT JULAH SEBAGAI DESA BALI AGA}

Agama dan Kepercayaan. Dalam Desa Julah juga terdapat peninggalan penting yaitu berupa prasasti perunggu. Terdapat kurang lebih 10 prasasti yang ada di desa ini (Brigitta, 
2008). Dengan usia peningalan tersebut, menunjukan bahwa desa Julah telah dihuni sejak zaman Paleolitikum dan Neolitikum. Pada jaman ini sistem kepercayaan yang dianut yaitu memuja Hyang (Ir. Sri Mulono, 1978). Hyang terkait dengan kepercayaan animisme dan dinamisme yang memuliakan roh nenek moyang dan roh kekuatan alam. Oleh karena itu kepercayaan yang turun temurun yang ada di Desa Julah adalah kepercayaan memuja leluhur (Sidemen, 2017). Tempat suci Desa Julah merupakan tempat stana untuk para roh leluhur yang telah meninggal. Masyarakat Desa Julah meyakini bahwa roh leluhur akan membimbing kehidupan mereka, dan jika terdapat sebuah kejadian-kejadian aneh yang terjadi pada mereka merupakan sebuah petunjuk yang diberikan oleh leluhur mereka (Sidemen, 2017).

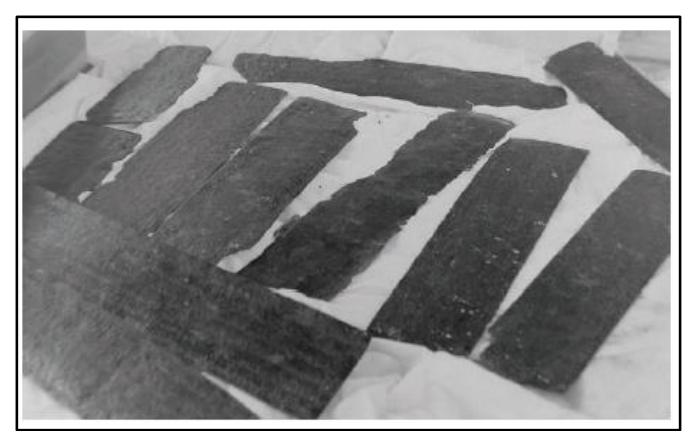

Figur 4. Prasasti Perunggu Sumber : Brigitta Hausser, 2008

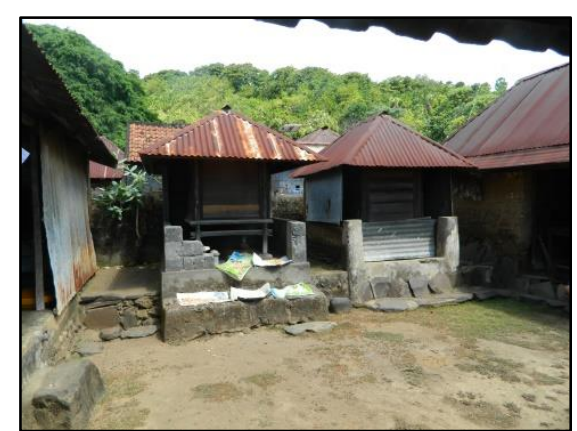

Figur 5. Tempat suci keluarga Desa Julah

Upacara dan Ritual (Kematian atau ngaben). Upacara kematian di Desa Adat Julah disebut dengan Pengabenan. Pengabenan pada desa adat Julah berbeda dengan pengabenan pada masyrakat Bali yang pada umumnya melalui proses pembakaran. Pengabenan pada desa adat Julah adalah upacara kematian melalui proses penguburan dan tidak terdapat proses pembakan sama sekali nantinya. Upacara kematian salah satu anggota masyarakat bersifat tanggung jawab satu desa.

Rutinitas Sehari-hari. Aktivitas anak-anak pada umumnya terekam pada sore hari. Hal ini dikarenakan pendidikan formal telah menyebakan keseharian anak-anak dihabisakan di sekolah. Kegiatan bermain anak umumnya berlangsung diluar kavling rumah. Sirkulas jalan utama yang umumnya menjadi tempat paling ramai untuk beraktivitas. Semakin sore, kegiatan bermain anak-anak kemudian dilanjutkan menuju ke arah pantai. Dewasa produktif banyak yang bekerja di luar desa sebagai buruh bangunan, juga buruh perkebunan. Sebagian dari mereka menghabiskan waktunya di luar desa dan hanya kembali ketika sore hari. Setelah itu mereka menghabiskan waktu malam hari untuk berkumpul dan berbincang-bicang dengan teman-teman seusianya. Biasanya tempat berkumpul umumnya di depan Pura desa ketika sore hari, sementara ketika semakin malam mereka menghabiskan waktu di depan jalan raya serta di Bale Banjar untuk sekedar berbincang ataupun bermain kartu.

\subsection{KONSEP PERMUKIMAN DESA ADAT JULAH}

Kepercayaan dalam Tatanan Permukiman Desa Adat Julah. Desa Adat Julah memiliki orientasi permukiman yang dipengaruhi oleh faktor alam yaitu ke arah gunung (kaja) dan laut (kelod). Adapun pembagian ruang atau wilayah desa dapat di jelaskan sebagai berikut:

1. Ulun: merupakan daerah teratas dalam tatanan desa yang digunakan sebagai tempat suci masayarakat desa yaitu Pura Desa dan Pura Puseh.

2. Teben: merupakan daerah terbawah dalam tatanan desa yang digunakan sebagai kuburan. 
3. Tengah/madya: merupakan kawasan permukiman disertai dengan tempat untuk melakukan aktivitas sosial. Pada area ini terdapat beberapa fungsi pendukung kegiatan sehari-hari seperti sekolah, pasar dan Bale Banjar.

Jika dikaitkan dalam kepercayaan lapisan dunia kepercayaan masayrakat Bali Aga, ketiga daerah dalam tatanan permukiman tersebut disebut dengan Tri Loka.

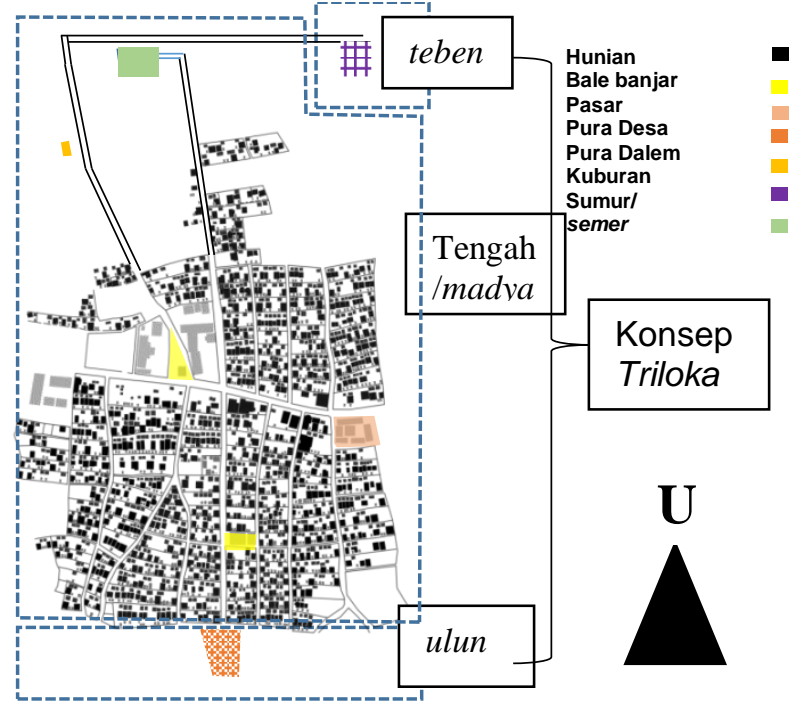

Figur 6. Pembagian zona permukiman

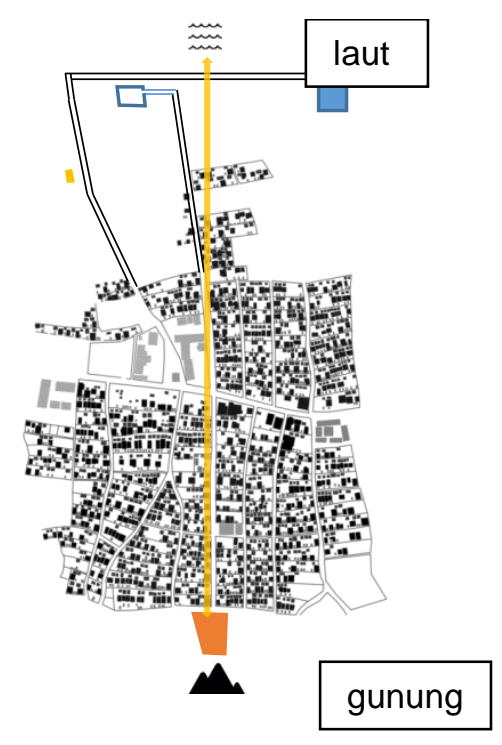

Figur 7. Orientasi Gunung-laut

Jalan utama desa yang memanjang dari arah selatan ke arah utara merupakan "pusat" yang tidak hanya berfungsi sebagai sirkulasi umum tetapi juga sebagai ruang terbuka yang dapat meningkatkan interaksi antar gang atau jalan setapak menuju pekarangan setiap unit rumah. Berdasarkan identifikasi terhadap fasad yang dibentuk, jalan utama tersebut memiliki hierarki yang utama dalam tatanan Desa Adat Julah. Secara fisik hal ini dapat dilihat melalui perletakan kori atau gapura sebagai gerbang depan di halaman pekarangan rumah. 


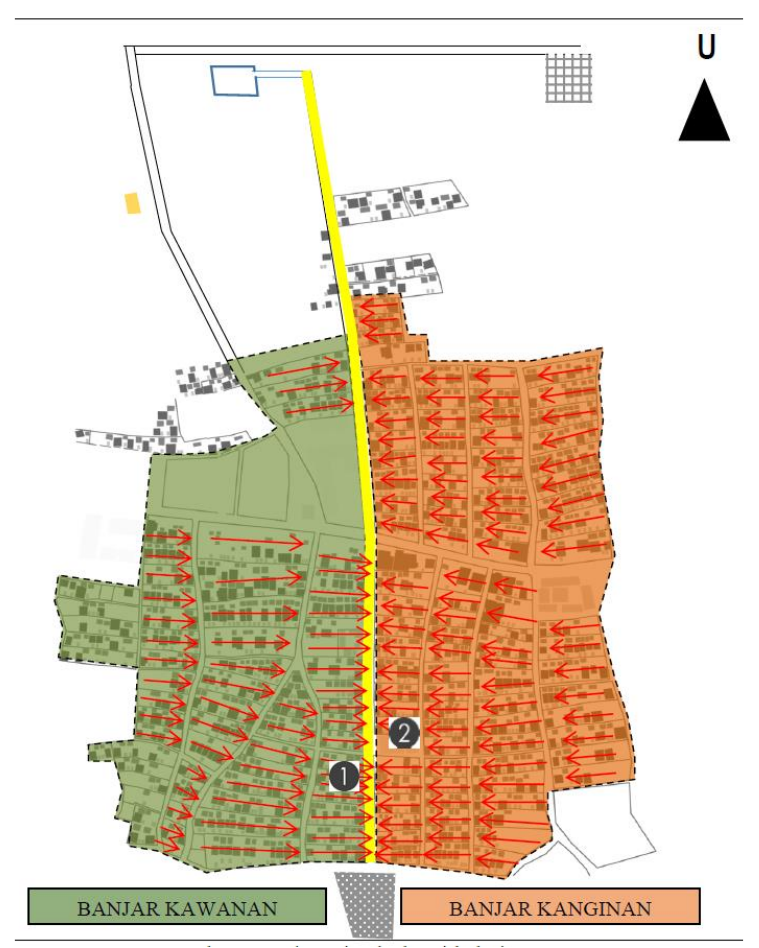

Figur 8. Orientasi terhadap sirkulasi utama

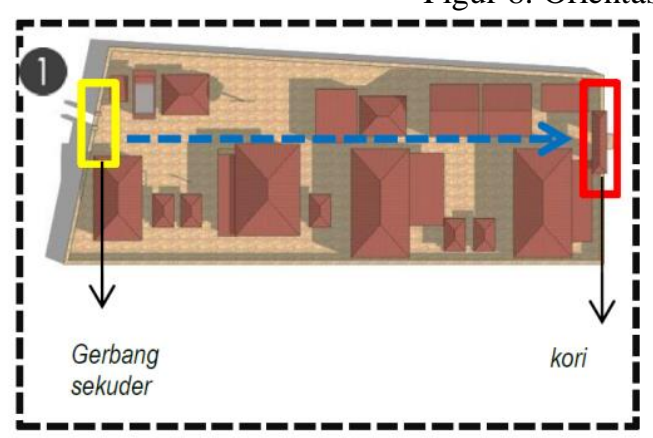

Figur 9. Salah satu di penataan hunian banjar Kawanan

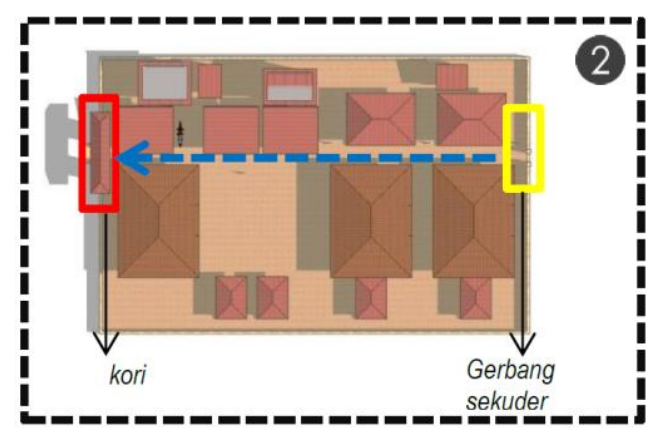

Figur 10. Salah satu di penataan hunian banjar Kanginan

Secara penataan skala makro dapat terlihat melalui peletakkan Pura yang terletak pada sisi selatan yang mengarah ke Gunung. Sementara pada skala pekarangan nampak pada tempat sucinya. Orientasi tempat suci pada pekarangan selalu berada di sisi selatan pekarangn rumah. Sementara, daerah yang dianggap kotor diletakkan di sisi utara. Daerah yang dianggap kotor dapat berupa kandang ternak, dapur dan kamar mandi. 


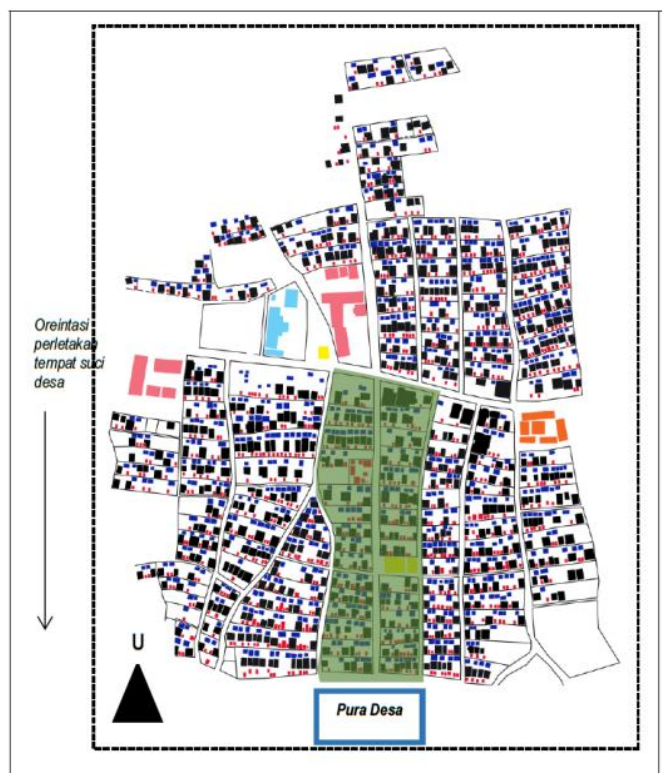

Figur 11. Orientasi pertletakan tempat suci dalam desa

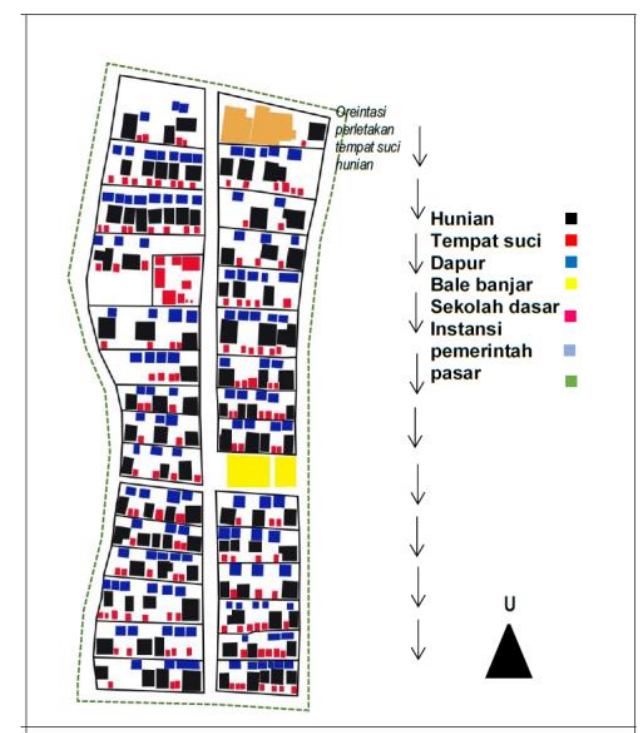

Figur 12. Orientasi perletakan tempat suci dalam hunian pekarangan

Ritual dalam Tatanan Permukiman Desa Adat Julah. Proses pengabenan merupakan salah satu upacara yang penting di Desa Julah. Pengerjaan wadah (sarana 'kendaraan' untuk membawa jenasah ke kuburan) mengambil tempat di sirkulasi utama desa. Sementara kegiatan persiapan seperti membelah bambu dan mengukur dan memotong bahan rangka wadah dilakukan di dalam Bale Banjar. Sirkulasi utama desa memiliki peranan yang penting dalam upacara ngaben.

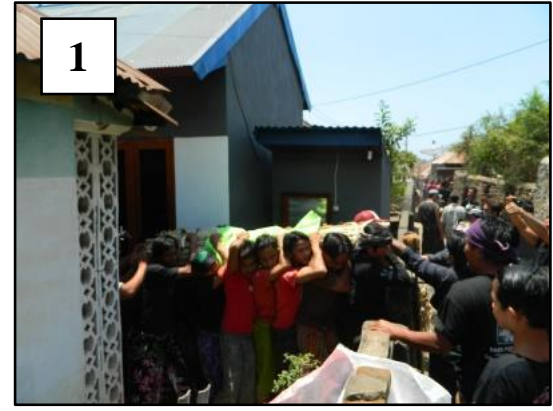

Figur 13. pengantaran jenasah dari rumah duka menuju wadah

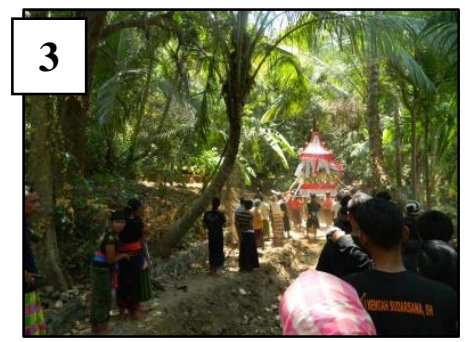

Figur 15. prosesi wadah di depan Pura Dalem

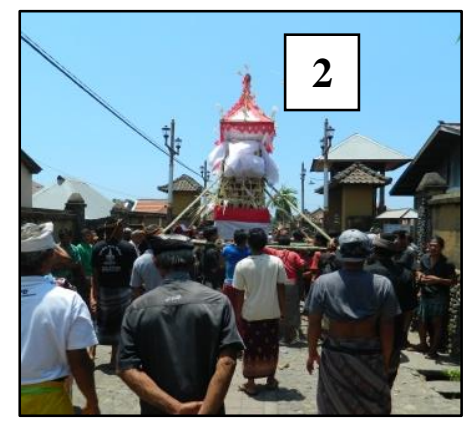

Figur 14. proses keberangkatan menuju Pura Dalem

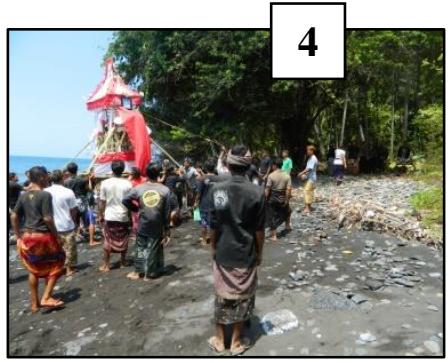

Figur 16. wadah telah berada di depan setra (kuburan)

Menariknya, bahwa di manapun lokasinya rumah orang yang meninggal, wadah harus diletakkan pada jalan utama desa. Pengantaran jenazah ke kuburan harus melalui jalan utama desa. Jadi, jika masyarakat desa yang meninggal berada di sisi yang utara, maka harus dibawa ke jalan utama yang di selatan. Begitu juga jika rumahnya disisi paling timur ataupun barat 
juga, proses keberangkatan menuju kuburannya harus dimulai dari poros utama desa tersebut. Kemudian, jalur yang digunakan harus jalur yang sama, baik saat berangkat menuju kuburan maupan saat kembali ke rumah duka. Dari runtutan proses keberangkatan jenazah ke kuburan dapat dilihat bahwa pada Desa Julah, jalan utama desa memiliki fungsi yang penting dalam kegiatan upacara.

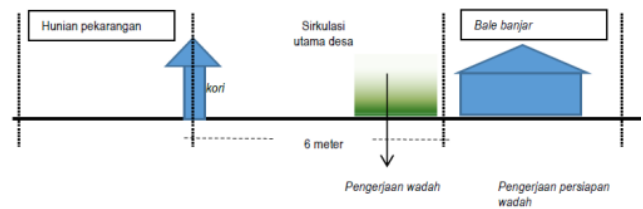

Figur 17. Pengerjaan wadah di depan bale banjar

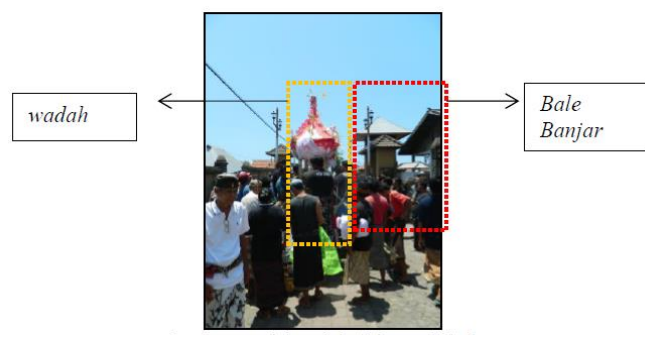

Figur 18. wadah di depan bale banjar saat prosesi keberangkatan menuju setra (kuburan)

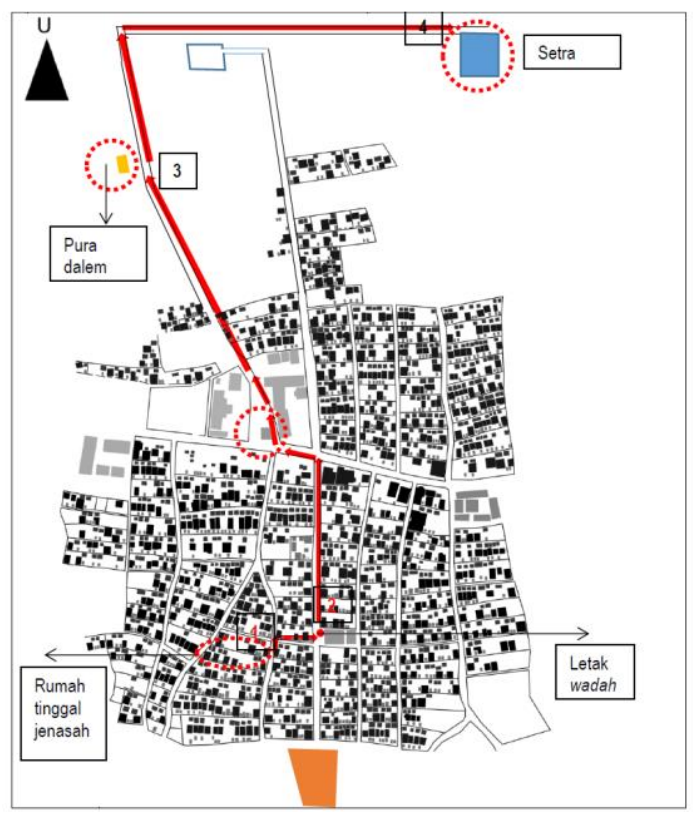

Figur 19. Rute ritual penguburan dari rumah duka menuju setra (kuburan)
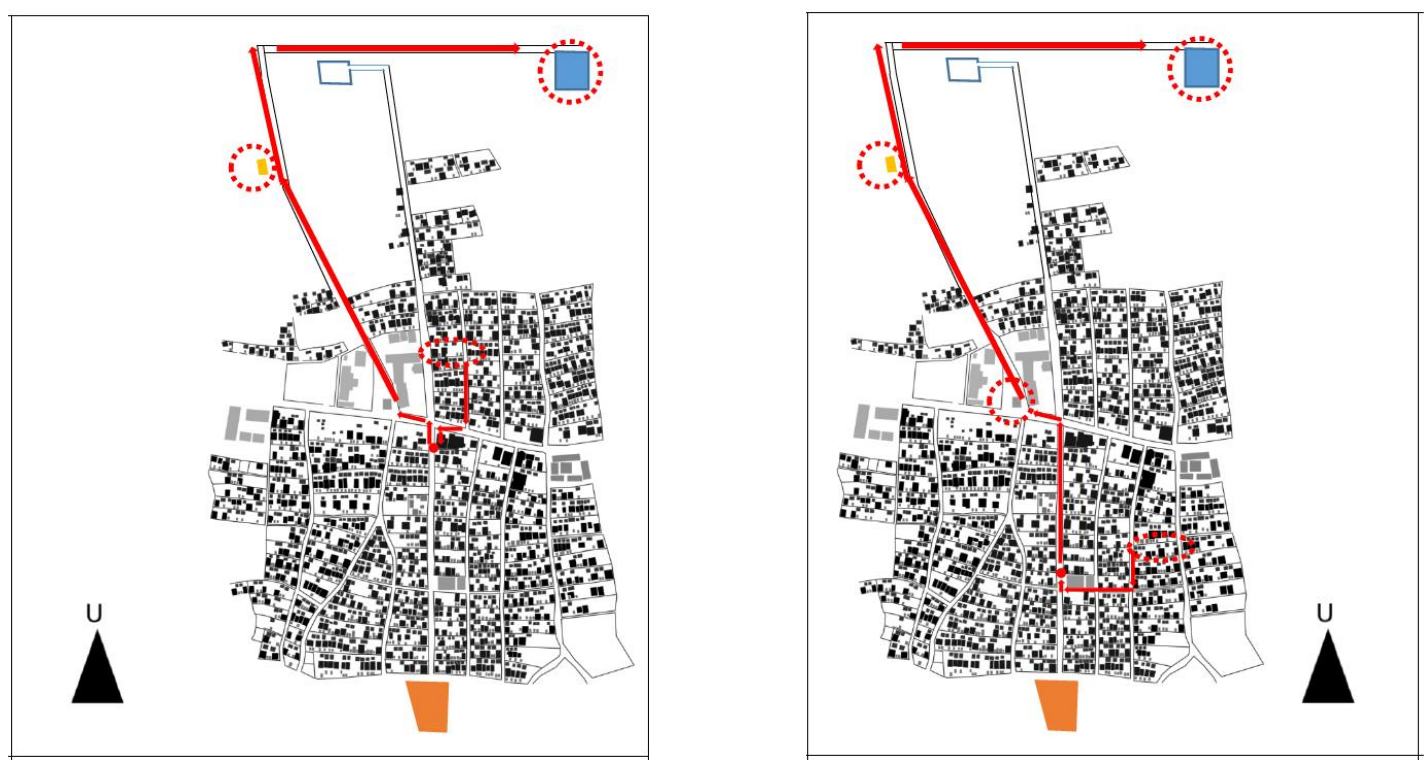
Figur 20. Ilustrasi jalan upacara dengan letak rumah duka di sisi utara desa
Figur 21. Ilustrasi jalan upacara dengan letak rumah duka di sisi timur desa

Rutinitas Sehari-hari dalam Tatanan Permukiman Desa Adat Julah. Pada Masyarakat Desa Julah, dapat dilihat bahwa kegiatan sehari-hari banyak terjadi di jalur sirkulasi utama desa. Jalur sekunder umumnya memiliki kegiatan yang lebih sedikit. Sirkulasi utama desa memiliki lebar yang lebih besar dibandingkan sirkulasi sekunder, sehingga kegiatan yang dapat dilakukan pada jalur tersebut lebih beragam

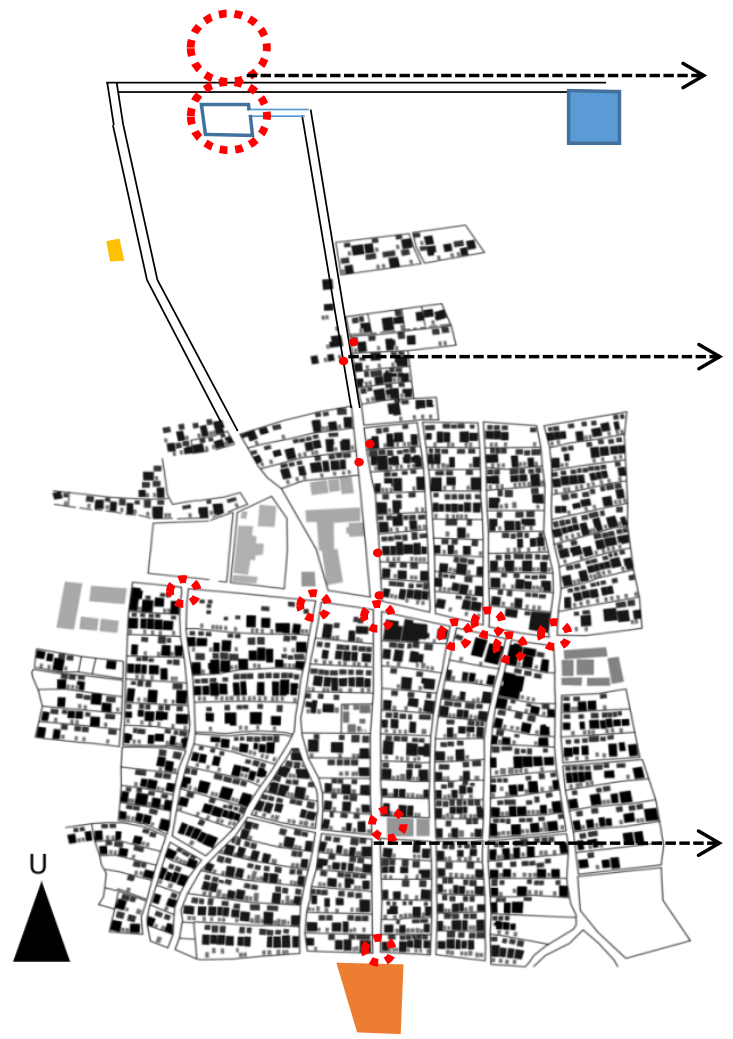

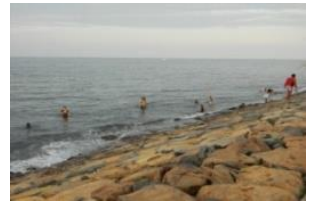

Gambar. Suasana sore tepi pantai Sumber : dokumentasi penulis, 2017

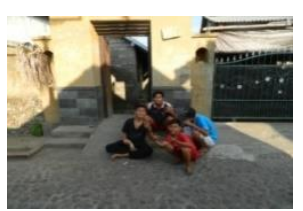

Gambar. Anak muda nongkrong didepan jalan desa Sumber : dokumentasi penulis, 2017

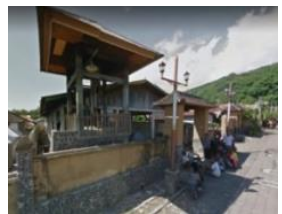

Gambar. Anak muda nongkrong didepan jalan desa Sumber: dokumentasi penulis, 2017

Figur 22. Titik aktivitas masyarakat

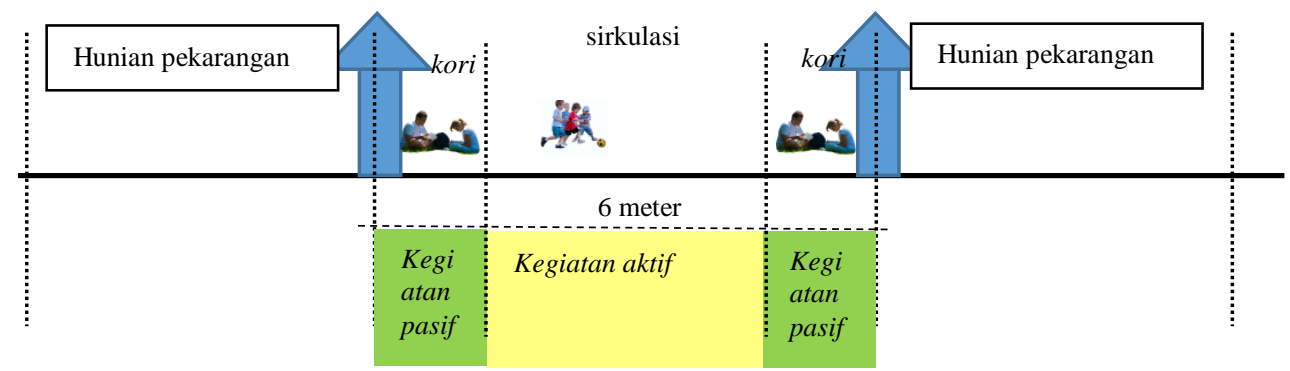

Figur 23. ilustrasi aktivitas pada jalur sirkulasi utama

Jalan utama desa biasanya menjadi tempat untuk berkativitas di sore hari. Pada umumnya, keramaian ditandai dengan anak-anak bermain di jalanan. Semakin sore kegiatan bermain anak-anak semakin ramai. Jalan utama desa dijadikan tempat bermain karena memiliki lebar yang lebih leluasa untuk bermain. Jalur utama ini memiliki lebar kurang lebih 6 meter. Sementara jalur sirkulasi sekunder desa hanya mimiliki lebar kurang lebih 1 sampai 1,5 meter.

Setelah selesai bermain di sirkulasi utama desa, biasanya dilanjutkan dengan menuju pantai. Kegiatan di pantai sangat beragam. Anak-anak umumnya berenang, sementara anak-anak remaja berbincang-bincang bersama temannya dan pada umumnya disini menjadi tempat para pemuda-pemudi berpacaran. Orang tua menemani anak-anaknya berenang di pantai 


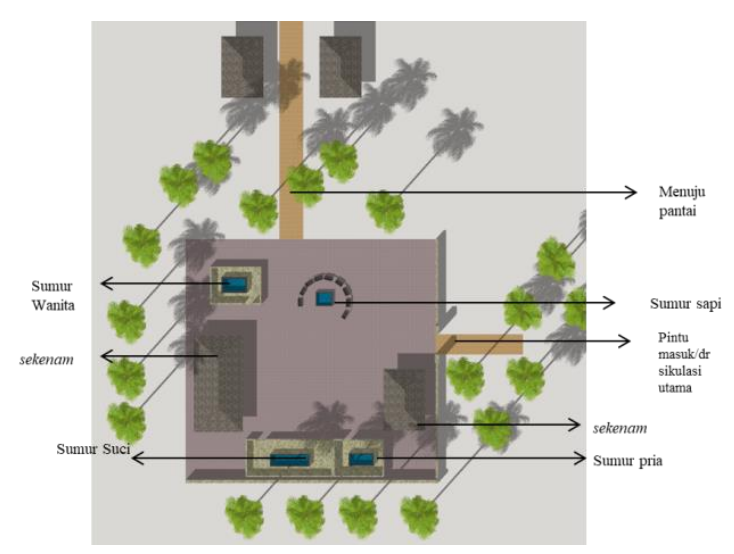

Figur24. Area Sumur Publik Desa Adat Julah

Dari rutinitas tersebut dapat dikatakan bahwa sirkulasi utama desa merupakan ruang terbuka yang berfungsi sebagai "pusat" kegiatan yang mewadahi aktivitas sosial masyarakat Julah. Selain nilai sakral ruang sirkulasi utama yang telah dijelaskan pada sub bab sebelumnya, ruang sirkulasi utama juga penting dalam tatanan desa sebagai wadah untuk rutinitas masyarakat desa.

Kepercayaan dalam Ruang Permukiman Desa Adat Julah. Adapun penjelasan dalam penelitian ini dibagi menjadi 2, yaitu berdasarkan hunian tradisional dan hunian saat ini. Filosofi yang mendasari pembangunan pada tingkat pekarangan adalah ulun-teben. Konsep ulun-teben ini juga serupa pada tingkat permukiman secara makro. Pada tingkat pekarangan, ulun merupakan tempat yang dianggap memiliki nilai yang lebih tinggi. Dalam hal ini masayarakat menganggap nilai yang lebih tinggi sebagai sesuatu yang dipercaya memiliki nilai kesucian atau nilai yang lebih bersih. Sementara itu, teben adalah daerah yang memiliki nilai yang lebih rendah atau dalam hal ini berkatitan dengan sesuatu yang dianggapnya lebih kotor. Dapur dan tempat suci terletak dalam satu poros yang saling berhadapan.

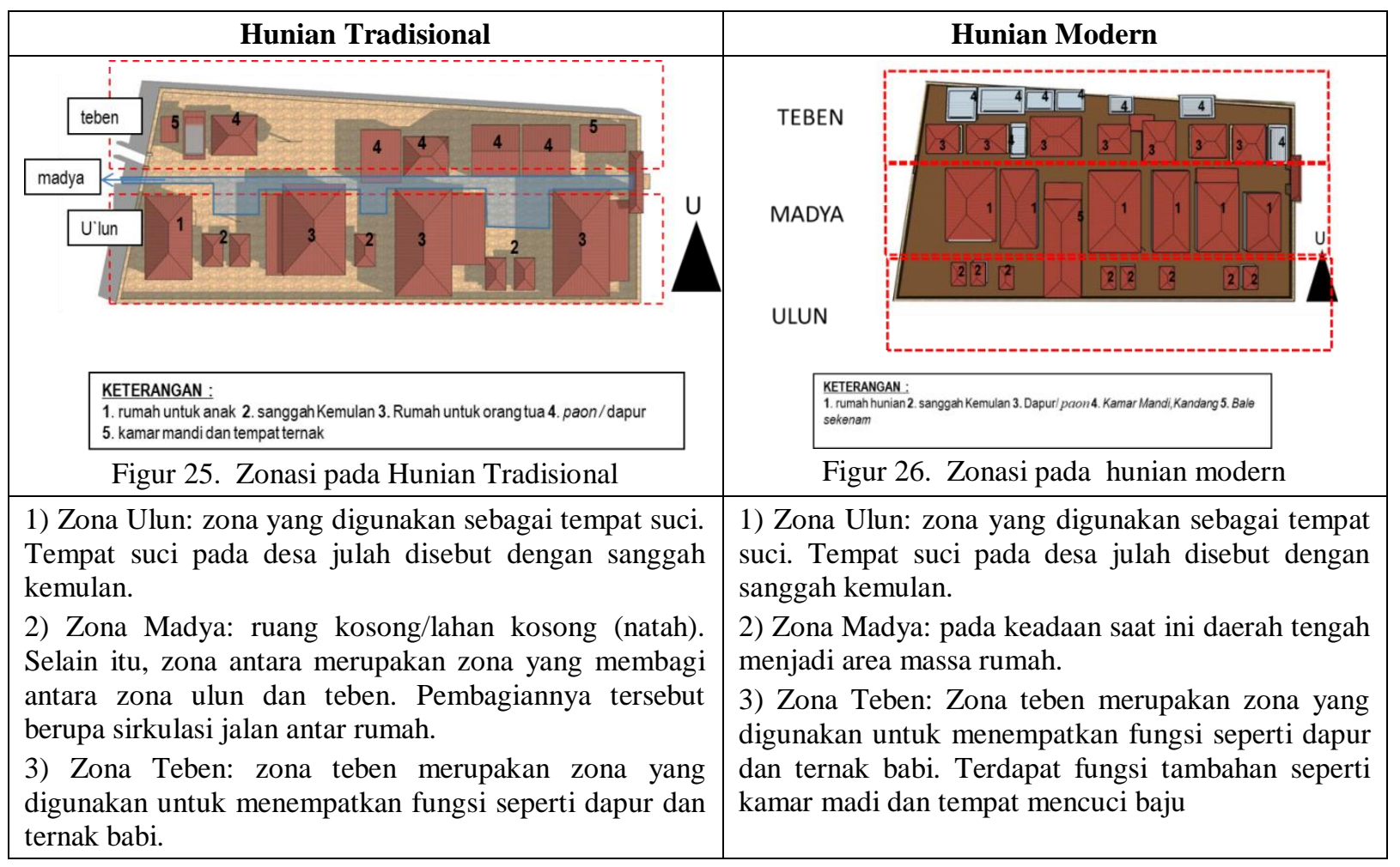




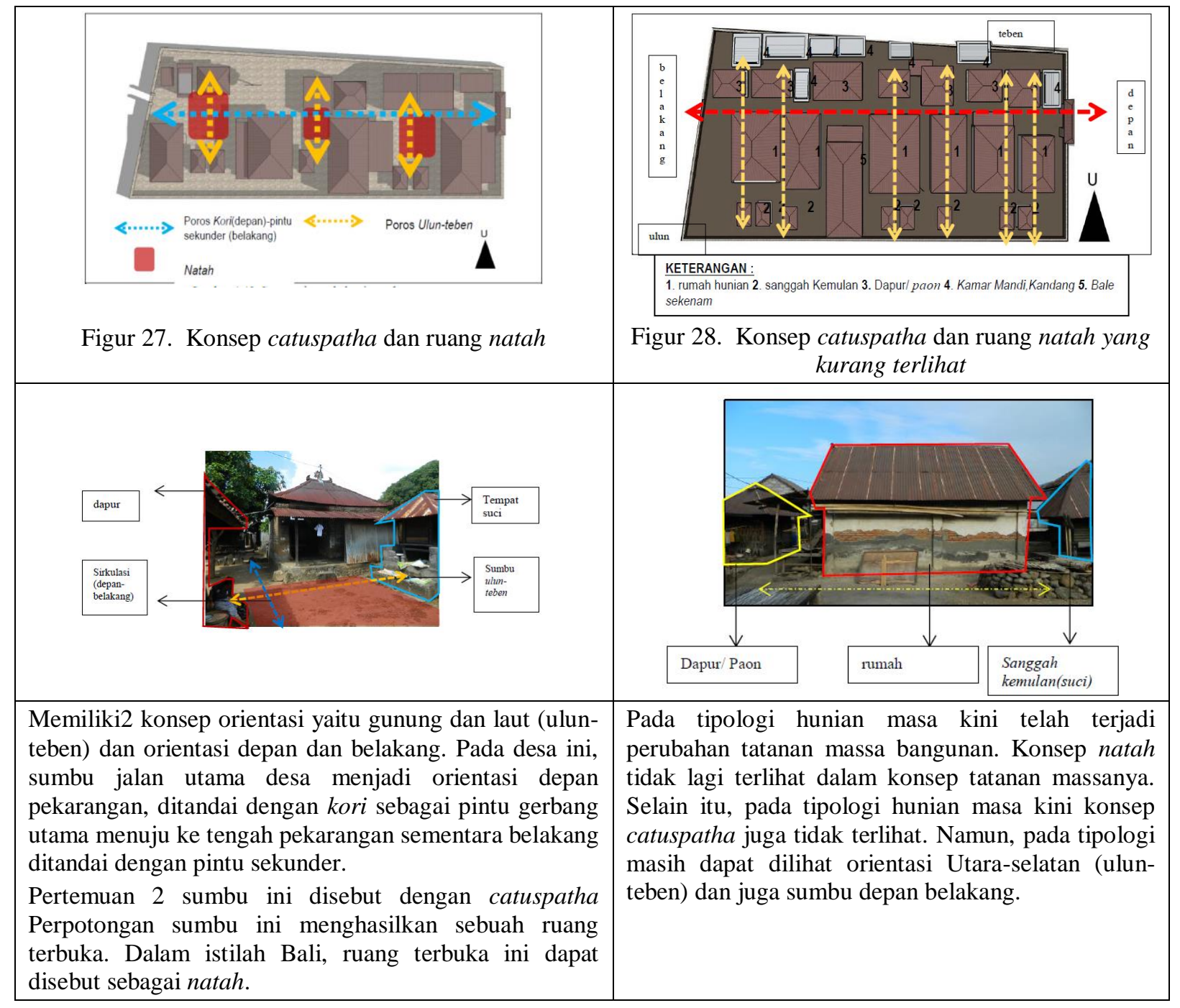

Ritual dan Upacara dalam Ruang Hunian Desa Adat Julah. Dari upacara tersebut dapat dilihat bahwa antar kepercayaan dan ritual saling terkait membentuk ruang natah dan catuspatha. Ruang ini sangat berperan dalam konsep bermukim desa Julah terkait penataan ruang pekarangan hunian. Dalam ritual tersebut ruang natah tidak hanya menjadi penting akibat ritual yang terjadi, tetapi juga ruang natah menjadi ruang terjadinya interaksi sosial baik antara sesama penghuni pekarangan rumah ataupun antar masyarakat lain yang membantu upacara dan berkunjung. 


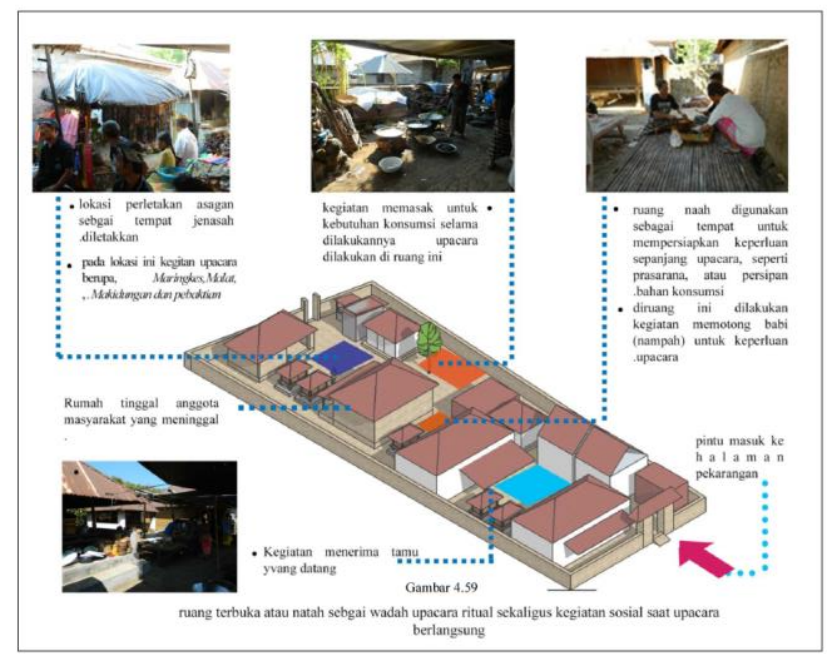

Figur 28. Peranan ruang natah dalam ritual kematian (ngaben)

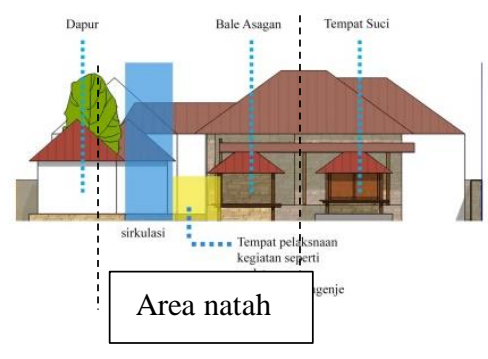

Figur 29. Potongan ruang natah saat pelaksaan riual ngaben

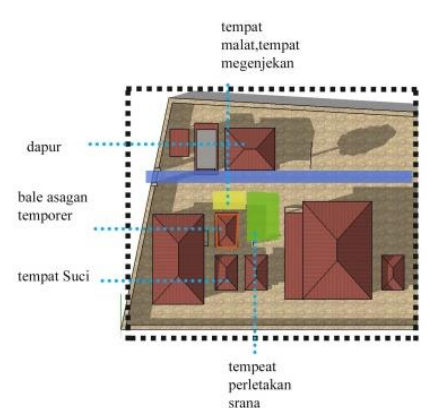

Figur 30. Denah ruang natah saat pelaksaan riual ngaben

Rutinitas Domestik dalam Ruang Hunian Desa Adat Julah. Kegiatan yang ramai umumnya mengambil tempat di sepanjang sirkulasi jalan dalam pekarangan, khususnya di bawah teritis atap antara ruang dapur dan hunian. Interkasi yang terjadi biasanya saat salah satu angota makan di dapur, kemudian anggota lainnya mengerjakan kerajinan tangan. Biasanya, interaksi terjadi dengan percakapan ringan saat salah satu anggota melewati jalan pekarangan. Masyarakat Desa Julah sering menggunakan area teras untuk berkegiatan.

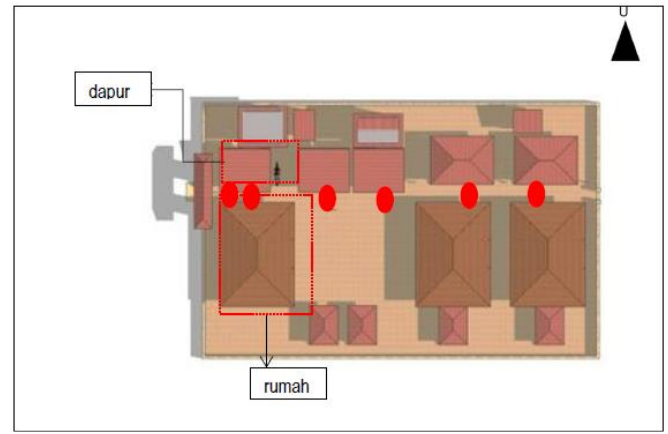

Figur 30. Titik-titik ruang interaksi

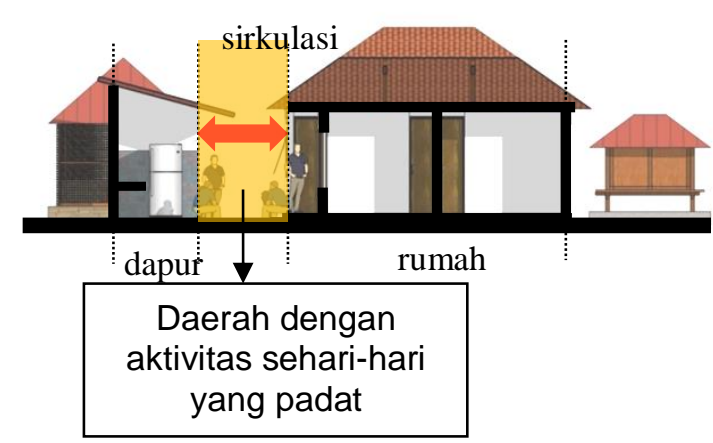

Figur 31. Area sirkulasi sebagai ruang interaksi

Kepercayaan dalam Bentuk Hunian Desa Adat Julah. Identifikasi hunian berdasarkan masa lalu dapat dilihat melalui penggunaan material dan berdasarkan hasil wawancara oleh pengguna. Pada hunian radisional material dinding yang digunakan berupa material tanah liat, struktur menggunakan material kayu dengan penutup atap berupa material 
seng. Identifikasi hunian berdasarkan masa kini dilihat melalui penggunaan material yang lebih modern berupa dinding beton dengan finishing dicat ataupun dengan material keramik.

\begin{tabular}{|c|c|c|}
\hline & Hunian Tradisional & Hunian modern \\
\hline $\begin{array}{l}\text { Massa } \\
\text { rumah }\end{array}$ & $\begin{array}{l}\text { Bentuk ini menyerupai analogi bentuk tubuh } \\
\text { manusia yang tersusun atas } 3 \text { bagian yaitu } \\
\text { kepala, badan dan kaki. Konsep ini serupa } \\
\text { dengan konsep Tri Angga. Dalam pembagian Tri } \\
\text { angga, terdapat pembagian utama, madya, dan } \\
\text { nista. }\end{array}$ & $\begin{array}{l}\text { Bentuknya masih memiliki bentuk masa } \\
\text { yang sederhana, dan tidak banyak mengalami } \\
\text { adisi ataupun substraksi. Komposisi } \\
\text { bangunan juga masih terlihat dengan jelas } \\
\text { anatar kepala, badan dan kaki bangunan. } \\
\text { Konsep Tri Angga yang erususn atas kepala, } \\
\text { badan dan kaki masih dapat terlihat }\end{array}$ \\
\hline Layout & $\begin{array}{l}\text { Jika dilihat berdasarkan arah untuk mencapai } \\
\text { masuk ke bangunannya, masa hunian anak dan } \\
\text { orangtua saling berhadapan. Begitu pula dengan } \\
\text { massa dapur dan tempat suci, kedua massa ini } \\
\text { juga saling berhadap. Olehkarena itu, } \\
\text { keberadaan keempat massa ini sangat } \\
\text { mengkuatkan adanya orientasi terhadap natah. }\end{array}$ & $\begin{array}{l}\text { Masa rumah memiliki banyak kamar. } \\
\text { Terdapat penyatuan ruang anak dan orang } \\
\text { tua. Terdapat perubahan diakibatkan lahan } \\
\text { yang berkurang. Konsep natah hilang. }\end{array}$ \\
\hline
\end{tabular}




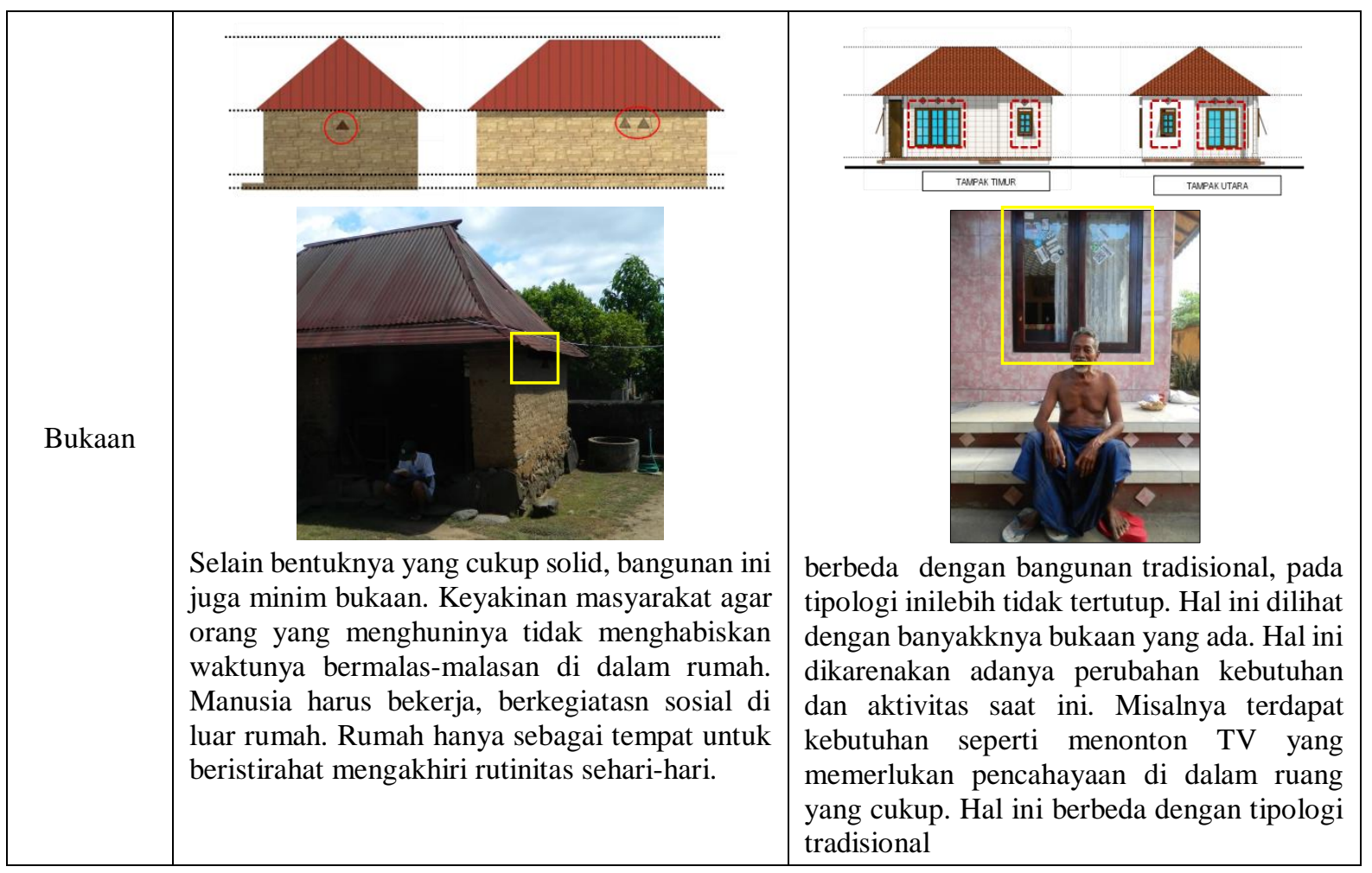

Rutinitas dalam Bentuk Hunian Desa Adat Julah. Adanya perubahan jaman telah menyebakan adanya perubahan aktivitas yang dilakukan. Keterbukaan terhadap mengikuti kebutuhan jaman menyebakan perubahan terjadi di masyarakat. Hal ini misalnya terjadi dengan adanya kebutuhan pendidikan pada anak-anak. Adanya kegiatan pendidikan untuk anak telah menyebakan adanya kebutuhan ruang belajar untuk anak-anak. Hal ini menyebakan adanya kebutuhan akan aktivitas di ruang dalam. Adanya kebutuhan ruang dalam menyabkan adanya perubahan keperluan akan keperluan kebutuhan ruang dalam seperti misalnya kebutuhan akan pencahayaan yang cukup. Hal ini menyebakan adanya kebutuhan bukaan yang lebih memadai. Hal ini dapat terlihat pada bukaan hunian saat ini yang lebih besar. Kebutuhan lainnya misalnya danya kebutuhan lain seperti menonton TV telah menyebakan adanya keperluan akan ruang dalam pula.

\section{KESIMPULAN}

Konsep bermukim Desa Adat Julah dipengaruhi kuat oleh faktor utama yaitu melalui sistem kepercayaan dan melalui pelaksanaan ritualnya. Perubahan rutinitas sehari-hari dapat dikatakan juga telah mempengaruhi terhadap konsep permukiman khusunya terhadap kebutuhan ruang. Adapun konsep bermukim Desa Adat Julah secara garis besar dapat disimpulkan sebagai berikut:

\begin{tabular}{|c|c|c|c|}
\hline & Kepercayaan & Ritual & Bentuk \\
\hline Tatanan & $\begin{array}{l}\text { Kepercayaan animisme dan dinamisme } \\
\text { menyebabkan adanya kepercayaan akan } \\
\text { faktor alam seperti Gunung dan Laut. Secara } \\
\text { tatanan, konsepsi yang dikenal juga sebagai } \\
\text { Tri Loka ( } 3 \text { dunia). Jalan utama sirkulasi } \\
\text { desa memiliki hirarki yang lebih tinggi.Jalur } \\
\text { sirkulasi utama sebagai arah depan/ hidup } \\
\text { yang menjadikan jalan ini menjadi orientasi } \\
\text { utama halaman depan hunian pekarangan }\end{array}$ & $\begin{array}{l}\text { Proses rangkaian upacara } \\
\text { kematian memperkuat } \\
\text { konsep Ulun-Teben.Ritual } \\
\text { kematian (ngaben) semakin } \\
\text { mempertegas keberadaan } \\
\text { jalur sirkulasi utama } \\
\text { khususnya bagian selatan } \\
\text { sebagai ruang terbuka } \\
\text { dengan hirarki utama di } \\
\text { dalam desa. }\end{array}$ & $\begin{array}{l}\text { Ruang sirkulasi utama } \\
\text { memiliki peran penting } \\
\text { sebagai wadah sosial non } \\
\text { formal yang menjadi ruang } \\
\text { terbuka untuk sehari-hari. } \\
\text { Sirkulasi utama desa ini dapat } \\
\text { dikatakan "pusat" kegiatan } \\
\text { sosial warga desa. }\end{array}$ \\
\hline
\end{tabular}




\begin{tabular}{|c|c|c|c|}
\hline Ruang & $\begin{array}{l}\text { Konsepsi Ulun-Teben juga terlihat kedalam } \\
\text { penataan halaman hunian pekarangannya. } \\
\text { Konsep Tri Angga ( } 3 \text { badan) yang secara } \\
\text { horizontal dapat terlihat melalui pembagian } \\
\text { area seperti bagian utama (hulu) tempat } \\
\text { bangunan suci, halaman tengah, dan } \\
\text { halaman kotor berupa dapur, dan kandang } \\
\text { ternak. Konsep hunian pekarangan Desa } \\
\text { Julah yaitu catuspatha. Konsep ini meyakini } \\
\text { pertemuan } 2 \text { sumbu imajiner tersebut } \\
\text { sebagai pusat dunia. Turunan konsep itu } \\
\text { adalah adanya ruang natah yang juga } \\
\text { memiliki peran penting dalam kegiatan } \\
\text { upacara seperti ngaben. }\end{array}$ & $\begin{array}{l}\text { Secara ruang, khususnya } \\
\text { yang terkait dengan hunian } \\
\text { pekaranganya, dalam } \\
\text { rangkaian upacara kematian } \\
\text { (ngaben) tersebut } \\
\text { menandakan pentingnya } \\
\text { ruang natah. Natah menjadi } \\
\text { ruang tempat } \\
\text { dilaksanakannya kegiatan } \\
\text { baik persiapan upacara, } \\
\text { penerimaan tamu hingga } \\
\text { tempat dilakukannya ritual } \\
\text { tersebut. Dapat dikatakan, } \\
\text { ruang natah merupakan } \\
\text { pertemuan antara aspek } \\
\text { spiritual dan aspek sosial. }\end{array}$ & $\begin{array}{l}\text { Berdasarkan ruang, dapat } \\
\text { dikatakan bahwa jalur } \\
\text { sirkulasi menjadi tempat } \\
\text { interkasi masyarakat. Terjadi } \\
\text { pertemuan antara aktivitas di } \\
\text { ruang luar rumah dan dapur } \\
\text { yang bertemu dengan orang } \\
\text { berjalan kaki pada jalur } \\
\text { sirkulasi. }\end{array}$ \\
\hline Bentuk & $\begin{array}{l}\text { Konsep Tri Angga ( } 3 \text { badan) yang secara } \\
\text { vertikal dapat terlihat. Konsep kepercayaan } \\
\text { terlihat dengan pembagian serupa dengan } \\
\text { pembagian tubuh manusia sebagai } \\
\text { perwujudan bhuana alit berupa kepala, } \\
\text { badan dan kaki. Meskipun adanya } \\
\text { modernisasi, namun konsep ini masih dapat } \\
\text { terlihat masih dierapkan pada bangunan } \\
\text { modern. }\end{array}$ & - & $\begin{array}{l}\text { Adanya perubahan rutinitas } \\
\text { yang menuntut mengubah } \\
\text { bentuk khususnya terkait } \\
\text { dengan layout massa rumah. } \\
\text { Adanya kebuthan saat ini } \\
\text { seperti menonton } \mathrm{Tv} \text { dan } \\
\text { kegiatan belajar anak-anak } \\
\text { yang dilakukan di dalam } \\
\text { rumah telah menyebakan } \\
\text { keperluan akan bukaan yang } \\
\text { lebih besar dibandingkan tipe } \\
\text { rumah tradisional. }\end{array}$ \\
\hline
\end{tabular}

\section{DAFTAR PUSTAKA}

Brigitta H, I Wayan Ardika. 2008. Burial,Text and Ritual:Ethnoarcheological Investigation in North Bali. Universitätsverlag Göttingen,Germany.

Oliver, Paul.2003. Dwellings. Phaiadon Press Limited, New York.

Oliver, Paul (1997). Encyclopedia Of Vernacular Architecture Of The World.New York, NY, USA : Cambridge University Press.

Rapoport, Amos. 1969. House Form and Culture. Pretince Hall inc. Englewood Cliffs.

Dwijendra,Acwin. 2009. Arsitektur dan Kebudayaan Bali Kuno. Denpasar: Udayana University Press. 